\title{
O LUGAR DA LITERATURA E DO CINEMA NA ESCOLA
}

The place of the literature and the cinema in the school

Marli Maria Veloso ${ }^{1}$

RESUMO: Este esboço tem como objetivo refletir sobre o lugar que a Literatura e o Cinema ocupam na escola. A partir da análise dos documentos oficiais que regem a educação brasileira, e, de como a escola insere essas duas linguagens na práxis pedagógica, como as concebe, como considera a relação dialética que estabelecem entre si e os pontos através dos quais essas artes dialogam, se aproximam, se afastam, se autorreferenciam, se complementam e exercem a função humanizadora. A escola deve se consolidar como instrumento de inclusão social e cultural, por ser um espaço privilegiado para o acesso à arte e para que a sua recepção e a sua dimensão social contribuam para a formação holística dos estudantes.

Palavras-chave: Literatura. Cinema. Escola. Recepção.

ABSTRACT: This draft aims to reflect on the place that Literature and Cinema occupy at school. Based on the analysis of some official documents that manage the Brazilian education, and how the school inserts these two languages in the pedagogical praxis, how it conceives them, how it considers the dialectical relationship they establish between themselves and the points through which these arts dialogue, approach, depart, self-refer, complement, and exercise the humanizing function. The school must consider itself as an instrument of social and cultural inclusion, since it is a privileged space for the democratization of access to art and so that its reception and its social dimension contribute to the holistic formation of students.

Key-words: Literature. Movie. School. Reception.

\section{CONSIDERAÇÕES INICIAIS}

$\mathrm{Na}$ conjuntura brasileira alguns mecanismos legais tentam garantir um lugar nas escolas brasileiras para as diversas linguagens artísticas. Dentre os quais, podemos citar a Lei de Diretrizes e Bases da Educação Nacional (LDB 9394/96), os Referenciais Curriculares Nacionais, os Parâmetros Curriculares Nacionais (PCN's)

\footnotetext{
${ }^{1}$ Mestranda em Letras - Universidade Estadual do Piauí. lilasveloso@yahoo.com.br
}

Cadernos Cajuína, V. 3, N. 2, 2018, p. 61 - 70.

ISSN: 2448-0916 
e as Orientações Curriculares Nacionais (OCEM), que representam um avanço no tocante aos objetivos da educação básica, estabelecem o direito do educando ao aprimoramento como pessoa humana incluindo a formação ética, estética e a autonomia do pensamento crítico.

Todavia, no tocante à Literatura e ao Cinema, nos documentos citados, a especificidade do texto literário é subestimada e o cinema aparece como sinônimo de entretenimento, embora haja a ressalva de que ambos os discursos são essenciais à formação dos educandos e que o diálogo que estabelecem entre si é produtivo para as duas artes.

Este cenário nos inquieta e nos impele a pensar sobre o lugar e a abordagem de obras literárias e fílmicas na escola, espaço privilegiado para o contato com a arte e que precisa se consolidar como instrumento de inclusão social e cultural, o que requer uma práxis pedagógica comprometida com o acesso à arte enquanto direito que traz em seu âmago "o que chamamos o bem e o que chamamos o mal, humaniza em sentido profundo porque faz viver" (CANDIDO, 2004, p. 176).

\section{CINEMA E ESCOLA: REFLEXÕES PERTINENTES}

Basin (1991) foi um dos primeiros a defender de forma incisiva o Cinema, enquanto signo híbrido, por sua capacidade de unir literatura, música, artes plásticas, história e memória, preconizando que não havia dano ou prejuízo algum para os textos literários se transpostos para o cinema, pois a literatura suscita imagens e o receptor, no ato da leitura, dialoga incessantemente com outras áreas do conhecimento e com outras artes. Esse entrecruzamento discursivo propicia a ampliação do horizonte que instiga o trabalho com a literatura e o cinema em sala de aula.

Quanto ao diálogo entre Literatura e Cinema o primeiro grande cineasta a expor preocupações teóricas acerca de sua arte, o russo Sergei Eisenstein, nos propõe que

Deixemos Dickens e toda a plêiade de antepassados, que remontam inclusive aos gregos e a Shakespeare, Ihes lembrarem mais uma vez que ambos, Griffith e nosso cinema, provam que nossas origens não são apenas as de Edison e seus companheiros inventores, mas se 
baseiam num enorme passado cultural; cada parte deste passado, em seu momento da história mundial, impulsionou a grande arte da cinematografia. Que este passado seja uma reprovação às pessoas inconscientes que trataram com arrogância a literatura, que contribuiu tanto para esta arte aparentemente sem precedentes e é, em primeiro lugar, e no mais importante: a arte de observar - não apenas ver, mas observar - com ambos os significados abarcados pelo termo. (EISENSTEIN, 2002, p. 203).

Desde 1915, quando o cineasta estadunidense David Wark Griffith dirigiu o filme O Nascimento de uma Nação, a junção entre Literatura e Cinema começa a se consolidar com a contribuição de diversas produções, dentre elas o filme Pollyana (1919), baseado na obra homônima de Eleanor H. Porter e Nosferatu (1922), baseado no livro Drácula, de Bram Stoker.

Assis Brasil (1967), fez um dos estudos pioneiros, no Brasil, estudando àquela época Cinema e Literatura. Para ele, mesmo com linguagens distintas e conservando características próprias, o cinema é a arte que mais se aproxima da literatura. As duas linguagens têm em comum o fato de serem essencialmente narrativas.

Movido pelo entendimento de que é preciso impulsionar a presença de arte na escola para possibilitar uma formação holística dos estudantes e propiciar que se tornem produtores e usuários de bens e serviços culturais na vida adulta, surgem medidas como a Lei 7.507/10 que torna obrigatória a exibição de filmes e audiovisuais de produção nacional nas escolas da educação básica por, no mínimo, duas horas mensais como componente curricular complementar integrado ao Projeto Político Pedagógico da Escola (PPPE).

No entanto, passados oito anos da promulgação da lei, é possível constatar que a mudança do cenário educacional nas questões concernentes à Literatura e ao Cinema também não ocorreu/ocorrerá por decreto, pois, nenhuma política de formação de leitores e de plateia logrará êxito sem formação docente adequada e sem a presença das obras no cotidiano escolar.

Candido (2004) pontua que nas sociedades desiguais a falta de democratização do acesso à cultura estabelece abismos entre os níveis culturais e postula que "[...] a fruição da arte e da literatura em todas as modalidades e em todos os níveis é um direito inalienável" (CANDIDO, 2004, p. 191). 
Compreendemos que, enquanto direito, o acesso ao objeto estético é essencial devido seu caráter libertador e dialógico, capaz de expandir as experiências e desconstruir estigmas, como ratifica Compagnon (2003, p. 37) ao referir-se à literatura: "A literatura confirma o consenso, mas produz também a dissensão, o novo, a ruptura." O autor enfatiza, porém, que a literatura não é o único meio de representar a experiência humana, visto que o cinema e outras mídias também são capazes de redimensionar a experiência humana e pondera que as narrações, sejam romanescas ou fílmicas, trazem em seu bojo a dimensão humana.

À luz do que nos ensina Candido (1995), entendemos humanização como

[...] o processo que confirma no homem aqueles traços que reputamos essenciais, como o exercício da reflexão, a aquisição do saber, a boa disposição para com o próximo, o afinamento das emoções, a capacidade de penetrar nos problemas da vida, o senso da beleza, percepção da complexidade do mundo e dos seres, o cultivo do humor. (CANDIDO, 1995, p. 249)

Literatura e Cinema estabelecem um diálogo humanizador com o receptor (leitor/espectador) por meio de narrativas, o que nos remete ao mito de Sherazade (exemplo no qual a narrativa, a narradora e a recepção estão interligados).

Quanto à complexidade de conceituação ante a essência da Literatura e do Cinema, há um ponto de interseção aos mais diversos posicionamentos: a possibilidade de identificação do texto com o leitor/espectador e, para este, a ampliação de seus horizontes de expectativas, através do processo de análise crítica fundamentada em sua experiência de vida.

Stam (2000) assevera que é possível estabelecer um paralelo entre o leitor e o espectador, pois a ambos cabe preencher, numa perspectiva dialógica, as lacunas do texto literário/fílmico sempre permeado de historicidade. Nesse ponto, encontramos um equívoco recorrente nas escolas nas quais estão presentes obras literárias e fílmicas: propõe-se aos alunos que encontrem os significados ao invés da proposição para que protagonizem a construção destes.

Para que a escola e o professor consigam desenvolver interesses de leitura que perdurem durante a vida inteira faz-se necessário que, no mínimo, se apropriem dos acervos disponíveis nas escolas, como: os livros que compõem o Programa Nacional da Biblioteca Escolar (PNBE) e os filmes da TV Escola e da Programadora Brasil e, que sejam leitores/espectadores capazes de discutir as conexões e estreitar 
as relações entre literatura, cinema e escola, repensar as concepções norteadoras da prática pedagógica e reavaliar a própria noção de Literatura e Cinema apresentada às crianças e aos adolescentes a partir das atividades desenvolvidas em sala de aula.

A escola deve conceber a Literatura e o Cinema pelo viés histórico, cultural e social que reflete os valores cultivados em cada momento histórico, que por sua vez interferem na leitura e balizam a atribuição de significados. Segundo Magnani (1989, p. 29) "é preciso repensar a dicotomia entre prazer e saber, além de pensar essas relações do ponto de vista de seu funcionamento sócio-histórico".

Nessa perspectiva o diálogo entre Literatura e Cinema se configura como uma necessidade cultural, consoante Hutcheon:

As histórias são, de fato, recontadas de diferentes maneiras, através de novos materiais e em diversos espaços culturais; assim como os genes, elas se adaptam aos novos meios em virtude da mutação por meio de suas "crias" ou adaptações. $E$ as mais aptas fazem mais do que sobreviver; elas florescem (HUTCHEON, 2013, p. 59).

Necessidade cultural que, quando satisfeita, gera uma relação dialógica através da qual florescem as adaptações (para além da questão da fidelidade) e que oportunizam que Cinema e Literatura compartilhem a mesma função: transmitir imagens através de palavras, naturalmente com linguagens peculiares.

Ao se tratar da linguagem do Cinema, Martin (2013) esclarece que:

[...] o que distingue o cinema de todos os outros meios de expressão culturais é o poder excepcional que lhe advém do fato de a sua linguagem funcionar a partir da reprodução fotográfica da realidade. Com efeito, com ele, são os próprios seres e as próprias coisas que aparecem, dirigem-se aos sentidos e falam a imaginação: a uma primeira abordagem parece que qualquer representação (o significante) coincide de forma exata e unívoca com a informação conceptual que veicula (O significado) (MARTIN, 2013. p. 24).

Concernente à linguagem da Literatura compreendemos que o conceito de literatura é fruto de um processo social e histórico e a leitura deve ser concebida como ação dinâmica, criativa, significativa e como processo de construção de sentidos e interação entre autor e leitor mediados pelo texto. Nesse viés, Lima contribui quando afirma que: "Como a palavra, como uma frase, como uma carta, assim também a obra literária não é escrita no vazio, nem dirigida à posteridade; é escrita sim para um destinatário concreto" (LIMA, 1979, p. 37). 
Partindo deste pressuposto encontramos uma mudança de foco nos estudos literários e fílmicos com a contribuição da Estética da Recepção a partir da década de 60 do século XX. Considerando o contexto no qual foram lançados os questionamentos que se configurariam como o manifesto da Estética da Recepção, na Europa os ventos sopravam em direção a uma mudança de paradigmas nos aspectos políticos, culturais e educacionais.

No tocante ao ensino da história da literatura a contestação se fundamenta no fato de que o mesmo estava reduzido às perspectivas das teorias marxista (que a partir de uma visão sociológica salientava a relação entre literatura e realidade social) e formalista (que reduzia o estudo do texto às estratégias verbais consideradas responsáveis pela literariedade) que relegavam o leitor a segundo plano e subestimavam sua bagagem cultural e simbólica que são de suma importância para a recepção.

Embora contestasse essas vertentes teóricas Jauss (1994) se apropriou das contribuições de ambas as teorias para estabelecer uma diretriz para o estudo da obra de arte com ênfase na relação entre o leitor/espectador e a obra, numa perspectiva dialógica essencial para que a experiência estética seja prazerosa e proporcione conhecimento e ampliação dos horizontes de leituras.

No campo da cinematografia, sob influência das teorias literárias, as amarras estruturalistas também começam a ser quebradas e o deslocamento do foco do texto para o receptor ganha força a partir da década de 70, quando o espectador deixa de ser visto apenas como um receptor passivo e um mero dado estatístico, momento no qual os estudos da sétima arte configuram-se como Teoria Fílmica a partir de pesquisas com abordagens distintas, sobre as quais Stam (2013) faz alusão ao ratificar que [...] muitos dos "momentos" teóricos - feminismo, psicanálise, pós-estruturalismo, teoria pós-colonial - são exasperadamente entrelaçados e convergentes; ordená-los de uma forma linear implica uma sucessão temporal que não existe (STAM, 2013, p. 17).

Nascimento (2008) enfoca que a Literatura e o Cinema oferecem a oportunidade de construir um espaço de liberdade e de transformação, numa abordagem que concebe as duas artes como de suma importância, sem a necessidade de hierarquizá-las e destaca que: 
El cine, al crear nuevos linguajes, al ofrecernos una forma diferente de contar las cosas, como expresión artística está, así como el texto literário, entre los bienes esenciales de la vida[...] (NASCIMENTO, 2008, p. 137) ${ }^{2}$.

Assertiva que nos remete ao conceito de bem incompressível apresentado por Cândido (2004), baseado nas proposições do filósofo francês Louis-Joseph Lebret, sobre dois tipos de bens: bem compressível e bem incompressível, estes dizem respeito aos bens que não podem ser negados a ninguém, e aqueles concernentes aos bens que podem ser dispensados. O crítico considera que são bens incompressíveis "[...] não apenas aqueles que asseguram a sobrevivência física em níveis decentes, mas os que garantem a integridade espiritual" (CANDIDO, 2004, p. 174).

Dentre esses bens Candido (2004) cita a alimentação, a moradia, o vestuário, a instrução, a saúde, a liberdade individual, o amparo da justiça pública, a resistência à opressão e também o direito à crença, à opinião, ao lazer, à arte e à literatura.

O nosso acreditar na importância da relação dialética a ser estabelecida entre autor/diretor, texto e leitor - mediada pela leitura e os seus desdobramentos - parte do pressuposto defendido por Silva (2005), segundo o qual a educação brasileira precisa de uma injeção de filosofia e de política para rompermos com a alienação, com a passividade e com a massificação a partir da ampliação dos horizontes de expectativas garantindo que cada criança e cada jovem possa desenvolver-se de forma holística com "criatividade, consciência da linguagem e consciência crítica" (COELHO, 2000, p. 130).

No tocante à função social da arte, compreendemos que o conhecimento de mundo é de suma importância para que a escola fomente ações que proporcionem a experiência estética e conduzam à formação para exercício da cidadania, pois no contexto no qual estamos inseridos muitos obstáculos permeiam o caminho, como os citados por Azevedo (2003):

Há problemas conjunturais tais como a existência de numerosos pais analfabetos ou semi-analfabetos, famílias dependendo do trabalho

\footnotetext{
${ }^{2}$ O cinema, ao criar as novas linguagens, ao oferecermos uma forma diferente de contar as coisas, como expressão artística está, assim como o texto literário, entre os bens essenciais da vida (NASCIMENTO, 2008, p. 137). Tradução da autora.
}

Cadernos Cajuína, V. 3, N. 2, 2018, p. 61 - 70.

ISSN: 2448-0916 
infantil para poder sobreviver, pessoas morando em casas, por vezes de um só cômodo, sem iluminação adequada para leitura. Há o preço do livro, alto para os padrões nacionais de renda, e a quase inexistência fora dos grandes centros, de livrarias e bibliotecas. Há o contato de crianças com adultos: pais e professores que apesar de alfabetizados não são leitores (AZEVEDO, 2003, p. 01).

Há que se considerar que no contexto brasileiro a ausência/escassez de equipamentos de cultura desafia a escola a se tornar um espaço de cultura e assegurar que a Literatura e o Cinema cumpram papel fundamental na transformação da sociedade, uma vez que, permitem ao ser humano compreender a si mesmo e relacionar-se melhor na realidade na qual está inserido.

De acordo com Aguiar (1998, p. 29), nessa relação o leitor/espectador deve perceber que "seu horizonte individual, moldado à luz da sociedade de seu tempo, mede-se com o horizonte da obra e que, desse encontro, the advém maior conhecimento do mundo e de si próprio".

\section{CONSIDERAÇÕES FINAIS}

Neste esboço apresentamos algumas reflexões sobre a presença da Literatura e do Cinema no espaço escolar, considerando alguns estudos teóricos e a nossa vivência docente nas escolas que nos consente reiterar: a Literatura ocupa um espaço secundário na escola e, via de regra, os textos literários são utilizados como pretexto para atividades gramaticais. Quanto ao Cinema, a situação é ainda mais aviltante por, nas raras aparições na escola, ser utilizado para ocupar aulas vagas ou servir de mero enfeite, ou entretenimento, durante algum evento.

Cabe à escola, assumir uma postura dialética, compreender as nuances das diversas culturas que a compõe e instigar os alunos a assumir o protagonismo num processo de abertura de novos espaços através da viagem pela imaginação, de construção da independência intelectual, de formação de autonomia e, sobretudo, de educação libertária que a garantia do direito ao acesso à literatura e ao cinema proporcionará se ambos forem inseridos de direito e de fato nos currículos escolares com o devido cuidado para o uso pedagógico não conspurcar o valor estético. 
Nosso intuito, ante a abrangência do tema, é refletir sobre questões concernentes à Literatura e ao Cinema para que ocupem, de fato e de direito, seu lugar na escola, e que outras e melhores considerações sobre a questão sejam suscitadas.

\section{REFERÊNCIAS}

AGUIAR, Vera Teixeira de; BORDINI, Maria da Glória. Literatura: a formação do leitor: alternativas metodológicas. 2. ed. Porto Alegre: Mercado Aberto, 1998.

BRASIL, Assis. Cinema e Literatura. Rio de Janeiro: Tempo Brasileiro, 1967.

CANDIDO, Antonio. Formação da Literatura Brasileira: Momentos Decisivos. 15. ed. São Paulo: Saraiva, 1995.

CANDIDO, Antonio. O direito à literatura. In: Vários escritos. 4. ed. Rio de Janeiro: Ouro sobre azul, 2004. p. 174.

COELHO, Nelly Novaes. Literatura Infantil: Teoria, Análise, Didática. São Paulo: Moderna, 2000.

EISENSTEIN, Sergei. A forma do filme. $2^{\underline{a}}$ ed. Rio de Janeiro: Jorge Zahar Ed., 2002.

HUTCHEON, Linda. Uma teoria da adaptação. Florianópolis: Editora da UFSC, 2013.

JAUSS, Hans Robert. A história da literatura como provocação à teoria literária. Trad. Sérgio Tellaroli. São Paulo: Ática, 1994.

LIMA, Luiz Costa (coord). A literatura e o leitor: textos da estética da recepção. Rio de Janeiro: Paz e Terra, 1979.

MAGNANI, M. Leitura, literatura e escola: sobre a formação do gosto. São Paulo: Martins Fontes, 1989. 
MARTIN, Marcel. A linguagem cinematográfica. São Paulo: Brasiliense, 2013.

SILVA, Ezequiel Theodoro da. Leitura na escola e na biblioteca. $10^{a}$.ed. São Paulo: Papirus, 2005.

STAM, Robert. Introdução à teoria do cinema. São Paulo: Papirus, 2003. 